\title{
Is it possible to implement ERP in the production function of civil construction?
}

\author{
É possível implementar ERP na função produção da construção civil?
}

\author{
Antônio Marcos Holanda de Sousa ${ }^{1}$, José de Paula Barros Neto² (D) \\ ${ }^{1}$ Universidade Federal do Ceará - UFC, Programa de Pós-graduação em Administração e Controladoria - PPAC, \\ Fortaleza, CE, Brasil. E-mail: amarcoshs@outlook.com \\ ${ }^{2}$ Universidade Federal do Ceará - UFC, Centro de Tecnologia, Departamento de Integração Acadêmica e \\ Tecnológica - DIATEC, Grupo de Pesquisa e Assessoria em Gerenciamento de Obras - GERCON, Fortaleza, CE, \\ Brasil. E-mail: barrosneto@gercon.ufc.br
}

How to cite: Sousa, A. M. H., \& Barros Neto, J. P. (2020). Is it possible to implement ERP in the production function of civil construction?. Gestão \& Produção, 27(3), e4445.

https://doi.org/10.1590/0104-530X4445-20

\begin{abstract}
This article aims to identify the critical factors of success for the implementation of an ERP system in the production function of civil construction. The results were obtained from a research of exploratory type, with a qualitative approach, having the multiple-case study as a research strategy and as a method of data collection an interview and thematic coding as an analysis tool. The research identified that the usage of ERP in the production function of construction companies is feasible and it brought as a new contribution to the subject the conclusion that the implementation success is much more related to the organizational policies (planning culture, strategic guideline and production management model) than the ERP features. This research also endorsed the critical factors of success already pointed out by the academia, such as the supplier's profile, the support from the senior management, and training. Regarding the training, it is highlighted the necessity to change the engineer profile.
\end{abstract}

Keywords: Civil construction; ERP; Critical factors of success; Planning; Implementation process.

Resumo: Este artigo objetiva identificar os fatores críticos de sucesso para a implantação de um sistema ERP na função produção da construção civil. Os resultados foram obtidos a partir de uma pesquisa do tipo exploratória, com abordagem qualitativa, tendo o estudo de caso múltiplo como estratégia de pesquisa e como método de coleta de dados a entrevista e a codificação temática como instrumento de análise. A pesquisa identificou que o uso do ERP na função produção das empresas de construção civil é viável e trouxe como nova contribuição ao tema a conclusão de que o sucesso da implantação está muito mais relacionado às políticas organizacionais (cultura de planejamento, o direcionador estratégico e o modelo de gestão da operação) do que às funcionalidades do ERP. A pesquisa também referendou os fatores críticos de sucesso já apontados pela academia, como o perfil do fornecedor, o apoio da alta direção e o treinamento. Em relação ao treinamento, destaca-se a necessidade da mudança do perfil do engenheiro.

Palavras-chave: Construção civil; ERP; Fatores críticos de sucesso; Planejamento; Processo de implantação.

Received Nov. 12, 2017 - Accepted Sept. 22, 2018

Financial support: None.

This is an Open Access article distributed under the terms of the Creative Commons Attribution License, which permits unrestricted use, distribution, and reproduction in any medium, provided the original work is properly cited. 


\section{Introduction}

The civil construction sector plays a relevant social and economic role in Brazil. Such importance is noted with its 5,8\% participation in the Gross Domestic Product (GDP) and in the job creation in the country, especially with the usage of workforce characterized as unskilled (CBIC, 2017).

Directly proportional to the importance of the sector is the complexity of its management and challenges to be overcome. A wide production chain, pulverization of suppliers, excessive informality, low investment both in technology and in the training of the workforce, as well as its turnover, are among the factors the contribute to make management even more complex (Ahmed et al., 2003; Etchalus et al., 2006; Skibniewski \& Ghosh, 2009).

Vieira (2006) also stresses, as a big challenge to be overcome, the lack of planning in the sector. That implicates in additional costs, frequent execution errors, wrong purchases (material and quantity), interruption of services, and waste.

Political and economic changes that happened in the past few years (economic stability, investments in infrastructure and housing, foreign competition) exposed the fragility of the sector, and have led businesses to reconsider their productive and administrative structures.

Studies such as the ones carried out by the Brazilian National Bank for Economic and Social Development (BNDES) or by the Federation of Industries of the State of São Paulo (FIESP) are examples of this movement in search of improvement in the sector. Among the alternatives for the improvement of the processes and the management, the Enterprise Resource Planning (ERP) systems are presented as an important tool (FIESP, 2008; Monteiro et al., 2010).

Tatari et al. (2007, 2008), Krainer et al. (2013) and Zeng et al. (2012) prove in their studies that the usage of ERP in the construction sector has brought improvements in the relationship between company and clients and increase on the results.

However, most of ERP implementations in construction businesses is restricted to the financial and human resources modules (Krainer et al., 2013), leaving out the data related to the production area, which is illogical, since ERP's goal is to ensure efficient management by integrating the data come from various areas of the organization.

It is important to see as activities of the production process all of those activities that happen from the early planning of the enterprise until its conclusion. Thus, the following macro activities were identifies: draw up planning, acquisitions (planning, procurement and reception), create job scheduling, execute scheduling, evaluate production, redesign.

Therefore, it is understood that the inclusion of the management of production processes in the ERP is imperative. Thus, to identify the critical factors of success for the introduction of such in the production area of the construction industry is the objective of this paper.

\section{ERP in civil construction}

ERP is a tool that aims to improve the management of organizations though the integration, standardization and process organization, the improvement in data quality and its flow in the organization, the gaining of data in real time and data sharing inside the organization (Sousa, 2014). 
Thus, it is created at the end the 20th century as a response from the software industry to the companies needs regarding better management and urgency in their decisions. It embodies countless features aiming to assist a bigger number of companies. ERP also transferred to the software industry the costs inherent to the development process and the functional technological evolution of the software (Kroenke, 2012).

Initially, oriented to assist the big companies, the software industry headed towards civil construction when the former, seeing the niche of big companies shrinking (late 90s), headed toward small and medium companies, where the highest volume of companies of the sector concentrated (Mendes \& Escrivão, 2002; Tatari et al., 2008).

Therefore, there were gaps between the processes offered by the ERPs based on a vision of management of companies of the industrial area and those demanded by civil construction (Shi \& Halp In, 2003; Pasqualini, 2005).

Table 1 sums up the functions that are particular to the civil construction sector, dividing them in groups by business and technical characteristics.

Table 1. ERP features to assist civil construction.

\begin{tabular}{|c|c|c|}
\hline Type & Characteristic & Author \\
\hline \multirow{9}{*}{ 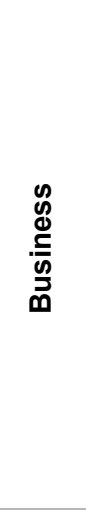 } & 1. Customization control & Sousa (2014) \\
\hline & 2. Workforce productivity control & Sousa (2014) \\
\hline & $\begin{array}{l}\text { 3. Building a precedence network of the project's } \\
\text { activities and schedules }\end{array}$ & Shi \& Halp In (2003) \\
\hline & $\begin{array}{l}\text { 4. Management of contracts and third-party } \\
\text { services }\end{array}$ & $\begin{array}{l}\text { Sousa (2014); O'Connor \& Dodd } \\
\text { (2000) }\end{array}$ \\
\hline & $\begin{array}{l}\text { 5. To follow the physical and financial evolution of } \\
\text { the enterprise }\end{array}$ & $\begin{array}{l}\text { O'Connor \& Dodd (2000); } \\
\text { Tatari et al. (2008) }\end{array}$ \\
\hline & 6. Settling of the costs & Sousa $(2014)$ \\
\hline & 7. Management of materials, stock and purchases & Sousa (2014); Tatari et al. (2008) \\
\hline & 8. Commercial planning (propositions and biddings) & Tatari et al. (2008) \\
\hline & 9. Availability planning and workforce allocation & Sousa (2014) \\
\hline \multirow{3}{*}{ 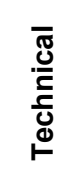 } & 10. Data extraction tool & Shi \& Halp In (2003) \\
\hline & 11. Ease of integrations with other systems & Shi \& Halp In (2003) \\
\hline & 12. Remote access & Sousa (2014) \\
\hline
\end{tabular}

Source: Adapted from Sousa (2014).

Let us observe that, except by item 8 , all of the other business characteristics pointed in Table 1 are related to the production function, as well as it is related to the planning. Without and efficient planning, customization control, purchase of material, and workforce allocation will impact on the service delivery, the cash flow, and the lack of people or their idleness.

It must be observed that the ERP provides the planning function based on concepts by PERT/CPM ${ }^{1}$, which implicates on the requirement for a consistent knowledge on planning, which contrasts with the companies resistance to plan, which becomes a critical factor to the implementation of ERP in construction companies (Sousa, 2014).

${ }^{1}$ Program Evaluation and Review Technique/Critical Path Method (PERT/CPM). 
From the technical point of view, remote access is important, since it allows the sharing of data between the construction manager and his crew and the company board of directors, enabling them to evaluate the performance and its impact to the organization, which is hampered by the geographical distribution (Shi \& Halp In, 2003).

\section{Critical factors of success}

Mendes \& Escrivão (2002) define the Critical Factors of Success (CFS) as the key conditions that need to be met for the company [or event] to succeed in its practice area. In that paper, the CFS are the factors that must be observed to ensure that the process of implementing the ERP succeeds.

The high failure rate in the projects of the ERP implementation attests the complexity of such process, since $90 \%$ of the complete ones finish over the budget, $40 \%$ are partly implemented, and $20 \%$ fail. (Laukkanen et al., 2005). That is why identifying critical factors of success plays an important role in helping the focus on the activities that are essential to the implementation success (Ram et al., 2013).

Mendes \& Escrivão (2002) solidified in their research, based on studies by other authors, 12 critical factors of success. They are: organizational change, commitment from the senior management, commitment from the users, suitability of features, assessment of processes, training, critical step, professionals with technical knowledge in business, supplier's trustability, project management, strategy and interdepartmental communication.

The CFS above are sorted by its prevalence. And it is not surprising that organizational change and commitment from the senior management are among the top ones, given the profile of the size of the construction companies (small and medium), in which financial, human and technical resources are reduced, and the senior management's support become even more important, since it is their responsibility the allocation of resources (Yang et al., 2007).

Akkermans \& Van Helden (2002) bring a relevant contribution by observing a strong relationship between the CFS, in other words, change in one of them would necessarily influence the other always in the same way. Therefore, if the "support from the senior management" factor was not treated properly, all of the other would be equally jeopardized, but when it was treated properly, all of the others would respond in a positive way.

\section{Analysis models of the process of ERP implementation}

It can be found in the literature many proposals for an efficient process of implementation, beyond the methodologies designed by the very suppliers. For this paper, the models assessed were the ones presented in Table 2.

Table 2. ERP implementation models.

\begin{tabular}{cr}
\hline Model & Phases \\
\hline Nascimento (2007) & $\begin{array}{c}\text { Definition of the necessity, definition of the problem or opportunity, } \\
\text { feasibility study, system analysis, project, implementation, tests, } \\
\text { procedure description, database conversion, and installing. }\end{array}$ \\
\hline Souza \& Zwicker (2003) & Decision, selection, implementation and usage. \\
\hline Bajwa \& Garcia (2004) & Conscience, selection, definition, implementation, and operation. \\
\hline
\end{tabular}

Source: Elaborated by the Authors. 
The goal proposed by the models is to organize the process of ERP implementation, dividing it into phases and suggesting activities in each of the steps to achieve success in the implementation. That way, any of the models quoted in Table 2 could be used as reference to the analysis of the process of implementation used by companies, since there is great similarity between them. For example, Nascimento (2007) understands the system analysis as a phase, while Souza \& Zwicker (2003) see it as an activity of the selection phase, or even the database conversion, which is treated by Bajwa \& Garcia (2004) as an activity of the implementation phase.

However, this paper chose the model by Bajwa \& Garcia (2004) for including in their analysis, not only the technical aspects of the implementation, but also the business influences and the ones extrinsic to organization. Given that ERP is a tool for improvement of organizational processes, it would not make sense to use a different approach.

Furthermore, the construction sector has business characteristics that differ from the industrial sector. In addition to the ones mentioned on the introduction, it has its production based on projects, production happens in the very usage site, with its own characteristics, in different geographic locations, and, to complete the production it is required a great variety of specialized productive features (Pasqualini, 2005).

Vieira (2006) understands that such productive structure may have caused the distancing between the company's decision-making processes and the construction site, which led to decoupling between the office decisions and the reality of the construction.

As it is seen on Table 2, Bajwa \& Garcia (2004) divide the implementation process in 5 phases. On each step it points out, from the business point of view as well as from the technology one, precedents (internal and external factors) that influence each phase of the implementation process, a set of key activities, which must be performed for a good data collection, and which product must be delivered on each phase.

In addition to the activities suggested by Bajwa \& Garcia (2004), there were other factors considered, some also quoted by them, for the recurrence with which they would appear, explicitly or implicitly, on the consulted literature and presented with CFS.

For example, the necessity to formalize the selection process (Tonini, 2003), with the creation of work groups to allow the analysis in a multidisciplinary way of the ERP adherence to the organization processes, of the technological aspects, the supplier's technical and functional knowledge as well as his financial health, besides paying visits to clients that use the system and conducting a contract analysis.

Considering the fact that ERP cannot cover every feature demanded due to the big variation of business models, it is necessary to decide whether it seems fit for the company to adapt to the processes provided by ERP, or to adjust it (customization) to the company processes. In order to help the decision above Luo \& Strong (2004) present as a decision criterion the relationship between the company's maturity regarding technology and its maturity regarding organizational changes. The organization must choose what is more comfortable for them, avoiding thus a big impact with the ERP implementation. Such decision impacts not only the activities to be developed, but also ERP's implementation and maintenance costs (Souza \& Zwicker, 2003).

Another factor to take into account is the implementation strategy, considering its impact on the project's volume of resources, costs and deadline. Souza (2000) identify two strategies: the Big-Bang, which is the implementation of all modules at once, with one date for the beginning of the operation; and the implementation in phases, in which the modules are successively implemented, with different dates for the beginning of the operation. 
Souza \& Zwicker (2003) add the small-bang strategy, derived from the implementation in phases, in which, with companies that possess more than one site, one of them is selected and all modules are implemented. The goal is to get the implementation experience and minimize the impact throughout the organization.

Some other factors that may impact on the process of implementation process are the lack of training on technology by the engineering professionals, the scarceness of information on the process of inserting ERP in construction, the implementation time, and the financial, technical and human resources limitations (Scheer et al., 2007; Chung et al., 2008; Zeng et al., 2012).

\section{Methodology}

Due to the small number of studies on the process of ERP implantation, combined with complexity of the sector and implantation process, an interpretivist paradigm was adopted, which imposes as the foundation of the knowledge structuration the interviewee's point of view, who's the agent of the process (Shi \& Halp In, 2003; Bajwa \& Garcia, 2004; Padilha \& Marins, 2005; Morgan, 2007).

As a result of such paradigm, the qualitative approach, which values the signification given to the theme by the participant, the field data collection, and direct communication between researcher and participant, seems to be the most appropriate (Creswell, 2010).

The shortage of knowledge regarding this subject (Chung et al., 2008) suggested an exploratory study with a comparative analysis, allowing to identify convergences or divergences on the processes adopted by the studied companies.

As a research strategy, the multi-case study was adopted, with the purpose of investigating the event on different environments, in order to ensure a wider view of the problem. Since "[...] it makes impossible the consideration of a great number of variables which does not need to have been predetermined, as it does in case of a survey or experiment" (Roesch, 2006, p. 26).

The selection criteria adopted on the cases were: acting on the civil construction subsector, having had chosen ERP for over three years, in order to ensure usage experience, having income above $R \$ 100$ million (U\$270,027,027.00²), to minimize the cost effects, adopting the same ERP software, to eliminate the differences of the product features, and easy access for the researcher. These criteria led to the selection of two companies (Table 3 ) that conducted their implantation processes through very distinct strategies, which met the requirements of this research.

Table 3. Researched companies.

\begin{tabular}{|c|c|c|c|}
\hline Company & Annual revenue & Enterprises & Jobs \\
\hline $\begin{array}{c}\text { A } \\
40 \text { years } \\
\text { Head office: Fortaleza }\end{array}$ & $\begin{array}{c}\mathrm{R} \$ 140 \text { million } \\
(\mathrm{U} \$ 34.374 .382,00)\end{array}$ & 30 (Northeast) & $\begin{array}{c}1.800 \text { direct jobs } \\
1.200 \text { indirect } \\
\text { jobs }\end{array}$ \\
\hline $\begin{array}{c}\text { B } \\
34 \text { years } \\
\text { Head office: Fortaleza }\end{array}$ & $\begin{array}{l}\mathrm{R} \$ 100 \text { million } \\
\text { (U\$ 24.553.13,00) }\end{array}$ & $\begin{array}{c}12 \text { (Ceará, São Paulo, Rio } \\
\text { Grande do Norte and } \\
\text { Amazonas) }\end{array}$ & $\begin{array}{c}1.500 \text { direct jobs } \\
1.800 \text { indirect } \\
\text { jobs }\end{array}$ \\
\hline
\end{tabular}

Source: Elaborated by the authors.

${ }^{2}$ Conversion made in accordance with the dollar value on April $11^{\text {th }}, 2018$, provided by the Central Bank of Brazil. 
For the data collection, the semi-structured interview was used conducted from a previously elaborated questionnaire based on the theoretical framework. This chosen strategy provides to the interviewee freedom on the exposition of ideas and to the interviewer, the possibility of adjustments according to his findings, and validation of data with other interviewees (Flick, 2009).

There were eight people interviewed on company $A$ and six on company $B$, divided in the sectors Board of directors, Construction coordination, Planning, Controllership, and IT. The interviewees were identified by the company letter plus a sequential by the order of the interview. For example, A1, first interviewee from company $A$.

The analysis was carried out though the comparison of the discourses from both cases, using as method the thematic coding and having as support tool the software MAXQDA (Flick, 2009). The comparability was ensured by the usage of the model by Bajwa \& Garcia (2004) as a guide.

Therefore, this research was exploratory in type, with qualitative approach, having the multi-case study as research strategy and as a method of data collection the interview and the thematic coding as analysis tool.

\section{Analysis of the process of ERP implantation in companies A and $B$}

The implementation process in the companies took distinct paths in the various phases. That was productive for the research, because by taking distinct action on the same assessment elements, it allowed the validation of the criteria suggested by the academia, as well as the identification of new elements. It will be analyzed in each step.

\subsection{Conscience phase}

On the conscience phase, in which must be identified the fragility points and needs of the company that could demand the usage of ERP, the organizations presented distinct needs.

Company A searched for a solution to improve its control, which was made manually through electronic spreadsheets, that provided low visibility on the resources available for construction (A5, A4). Thus, it has as its focus the quality of data and management decision-making.

Due to the fragility, or even absence of well-defined controls, company A intended to find in the features provided by ERP a solution for its demand. This decision created a dependency from the supplier's crew, which brought hurdles to the project, since the supplier did not have maturity neither on the product, nor on the construction sector (A1).

On the other hand, company $\mathrm{B}$, which had mature controls, searched for integration and reliability of data. The data were located in various systems and there was no coherence among them. According to interviewee B1, "[...] you would take a report, there would be a result, then you would take another and there would be another result".

From the technology point of view, the constant flaws from some of the systems, due to their technological architecture, were another reason for the adoption of ERP by company $\mathrm{B}$.

The research identified as a critical factor of success the need to have the controls well defined, since those, or the lack of them, impacted on the next steps. In case such controls do not exist, it is suggested that, before the beginning of the selection process, the company makes an internal study to identify which controls are needed, because 
the system features, analyzed on the selection step, depend heavily on the goals of the organization. The importance of the conscience phase resides on the identification of the goal to be achieved or the problem to be solved, thus, all subsequent actions will be marked by it.

\subsection{Selection phase}

The selection phase is the step that aims to choose the ERP that will be adopted. One of the determining factors to that choice, in both companies, was the supplier's profile. The fact that the product belongs to an acknowledged as solid was decisive (B6, A4). Such decision seemed to be the right one, because it is identified, in the organizations discourse, the statement that there was evolution on the product (A7, B1) and thus the limitations and deficiencies have been being overcome, as well as improvements being implemented.

It stands out, however, also for both companies, the lack of the supplier's maturity, not only regarding the product domain (B3), but also the knowledge on the construction sector (A5). That became more serious to company A, which saw in the ERP adoption a support for the improvement of their controls. The interviewee A5 understands the he could have hired a consultant to help on the process, however, excessive confidence deterred him from the idea.

The importance of the here identified supplier's profile contrasts with what was identified on the research by Mendes \& Escrivão (2002), who see this CFS as hardly relevant. Maybe one of the reasons of such contrast is the fact the ERPs are implemented in construction companies mostly just in administrative areas (Krainer et al., 2013), however, it was noticed in this research that the supplier was identified as a very relevant CFS.

Regarding the selection process, company $B$ stablished a formal process of product selection (A5, A7), which means the constitution of a team, the pondering of suppliers, and the functional assessment. However, they acknowledge that they should have deepened the analyses and that they put excessive trust on the supplier. Company $B$ adopted ERP as an evolution of the product (B3, B6), since they were already using other products from the supplier and only migrated to an integrated version.

However, unlike company A, which adopted ERP in all sectors, company B did not adopt it at the production sector, choosing to develop a solution of its own (B1, B7), because they understood that their processes were very particular and ERP did not provide the proper support. Interviewee B1 reassessed his decision through the research process, in the face of the features now provided by the ERP. It is understood that it strengthens the supplier's profile as a CFS for keeping investments on improvements for the product. On the impacts of such decision, it will be discussed on the next section.

To analyze company B's decision, it must be considered that the ERPs support their planning function on the model PERT/CPM, which has as its foundation of planning and control (including financial) the physical evolution of the endeavor. According interviewees B1 and B5, this kind of control was incompatible with the need of the company, which needed a control based on their cash on hand. It is understood that this was one of the most relevant factors on the decision, since it was the divergence between the model proposed by the ERP and the one desired by the company that led the latter to build a specific system for their production control. 
The decision is a nonsense, given that considering the physical process of the enterprise implicates on the identification of the appropriate period of the allocation of resources avoiding waste; it allows greater visibility over the cash flow throughout the enterprise; it allows to control the deliveries, which is important to the financing operations that bind the payments to the delivered steps. In other words, it allows more efficient planning, which can reduce the financial costs of loans, as well as anticipates receipts because of the building delivery.

It is understood that this decision is related to the strategic guideline, element that guides the decisions of the organization, which, in turn, is covered in the cost That way, all of the controls relegate planning to second place, focusing heavily on the financial controls, as it was identified by analyzing the results and control reports used by the board of directors.

The strategic guideline, and based on the cost, was identified as a new CFS, and it was one of the major factors for the development decision. The fact that company $B$ leave to each construction engineer the way of planning and controlling the enterprise (B4, B5 e B6), making necessary just to send to the matrix the financial data for the analysis of results, to support this idea, since, from the functional point of view, even with restrictions, the ERP met the requirements presented on the theoretical framework, except concerning the question of customization control and appropriation of the workforce costs.

The analysis of the selection process of the companies identified as critical factor of success the necessity of a formal process of choice, aiming to analyze the supplier's profile (technical, financial, and support to customer and product) and the ERP features. It also identified as a new CFS the strategic guideline as an element the influences management and, consequently, the controls and processes. That should be, as well as the desired controls, to be performed as soon as the conscience phase.

\subsection{Preparation phase}

The preparation phase has as its main goal the planning of the implementation process.

Both organizations followed the criteria suggested by the model, which is the adoption of working groups that aimed to take decisions on changes or to propose improvements and adjustments (A4, B5). Both also reported the support from the senior management as fundamental for the success. Company $B$ even had a member of the board of directors in the working groups, which brought speed to some decisions (B5). In company $A$ the process was under responsibility of a member of the board of directors.

The organizations began the implementation process at their offices and then headed to the construction.

Company A chose to use a pilot construction in order to create learning and to eliminate basic mistakes. However, they acknowledge that the testing time was very short, which compromised the learning in the implantation crew, leading them to make the same mistakes as the other units (A5).

Due to the fact that civil construction has a projectized organizational structure adn to the great impact on the organization with the ERP implementation, it is suggested the use of pilot construction for the knowledge consolidation and identification of problems coming from the changes. 
Concerning customization, company A chose to adopt the ERP's standard routines, adapting to them (A4, A5). Considering the little experience with technology, and how they were searching for a management model, they thought it was best to adapt themselves and, if necessary, in the future, to make some adjustments. They also worried about the impact on the organization change, since apart from the ERP, there were other changes underway.

According to Luo \& Strong (2004), that is the most appropriate strategy when the company has no experience with organizational changes e on the domains of technology.

On the other hand, company B's implementation strategy was on on the opposite direction. As they did not identify in the ERP an adherent solution to their processes, they chose for the development of a system. which brings reflections until this day. Among them is the maintenance of a development crew, the maintenance cost and product evolution, the high cost of learning for the new employees, as well as the difficulty of adoption of the improvements presented by the ERP through the years, given the great complexity of the systems developed in parallel.

Such decision from company $B$ raises an important point about the ERP. It cannot be treated as just a technology issue. The participation of the board of directors is important not only to eliminate conflict problems, but also to make decisions that will bring long-term impact. From there comes also the need for assessment of competence of the IT crew, which must signalize the decision impacts, or even the usage of specialized consulting, when the internal crew are not capable of meeting that demand.

Bajwa \& Garcia (2004) suggest that the analysis of the gaps between the system and the process must be made during the implementation step. However, the research identified that it is more appropriate to be done during the preparation phase, keeping in mind that during the implementation process there might be the need for replanning. That way, it is possible to define the proper training on the system and to identify the need for additional training for the crew.

In this additional training is the engineer's profile change, who became responsible for functions that were previously performed by the office (payroll, invoice entry etc.) and by demand of a planning culture, which, according to what participants B1, B3, A7 e A8 affirmed, it still is too incipient in these professionals.

At this phase, it was identified as a critical factor the need for deep analysis on the adherence to the ERP processes or to its customization, the adequacy to people for the new procedures, especially engineers, the support from the senior management, and the use of pilot construction.

\subsection{Implementation phase}

The implementation phase is the one in which the system begins to come into operation and the conflict points between the company's routines and the ones provided by the system become more evident.

The training was identified as a critical factor of success, which agrees with was suggested by Bajwa \& Garcia (2004). Company A even created video lesson on the usage of the system, with focus on the planning routines, something that was considered a differential (A2, A6).

The training was mentioned in both companies as a critical factor of success and its importance lies not only on enabling people to the usage of the system, but also on 
the reduction of resistance to the implementation. This finding meets with the research by Mendes \& Escrivão (2002) which brings training as a relevant CFS.

There was no consensus on whether the geographical distribution factor interfered on the training process, but the video lessons had as motivation the distance of the units. It is suggested, therefore, that geographical distribution be taken into consideration on the training programs, and that suppliers who provide distance training tools have differentiated scores.

It was identified that, besides the engineer, the stockman function has been through relevant changes, because after the ERP implementation he becomes responsible for settling the costs by pointing out the exits of material and the entry of invoices (materials and services), which demanded the necessity for tax knowledge (A6, B5).

In both companies, there were deficiencies identified in the registration of materials and budget composition, which demanded time for adjustment. The registration of materials has direct impact on the settling of the costs (A1) and the budget composition (A4). Moreover, the quality of the data is directly linked to to the way that it is registered; thus the creation of generic products must be avoided (A4).

Furthermore, it was identified, based on company A's experience, that the definition of $\mathrm{ASP}^{3}$ is a critical factor of success for the ERP implantation, opinion held by all interviewees from company $A$, as well as some interviewees from company $B$.

There was no doubt about the importance of ERP. The reasonings were concerning its level of detail and that it must be carried out in a way that allows the planning of purchases of services and material, the definitions of the crews, the building of the critical path (PERT/CPM model), the control of the physical evolution of the construction and the identification of the service performed, as much for the settling of the cost as for the work planning.

Regarding the external influences, though technology bias it was identified the necessity for an infrastructure of efficient communication, which many times conflicts with the quality of the services provided by the operators. That has a direct impact on the system usage, because it can make it slow or unavailable. Thus, the inconvenience of the lack of service is a factor of resistance to the ERP implementation (A1, A2, A6).

It is suggested that the activities concerning the registrations are performed as soon as the preparation phase, since it avoids problems during the implementation phase, eliminating resistances to the ERP. Moreover, it allows an assessment of the adequacy of the model of operation management to ERP through the building of the ASP and the controls derived from such structure.

Thereby, at the implementation phase, it was identified as a CFS the review of product registrations, the compositions, and the definition of ASP, the training, the stockman's and engineer's capacitation. The first as a result of the incorporation of new activities and the necessity of tax knowledge and the second because of the demand for knowledge on planning for the good usage of the ERP and the assimilation of new management activities. The infrastructure of telecommunication is also a critical factor, because that is what enables the access to the ERP.

\subsection{Operation phase}

The operation phase is the phase in which the system starts to be a part of the organization's day to day life. At company A, nowadays, the management does not identify any divergences between the company's processes and the product usage,

${ }^{3} \mathrm{ASP}$ - Analytical Structure of the Project. 
and they are finalizing a review on the ASP structure to fix some limitations in controls that still persist since the implementation. That, however, is in accordance with what Bajwa \& Garcia (2004) call organizational learning, in other words, actions of improvement on the process, which is not necessarily a problem.

However, the research identified that there are parallel control at the construction, such as the weekly work programming (A3) and the creation of the service order (A1), which only at the end of the month are added to the system. Part of the problem is related to the ASP structure and with the decision of not allowing the engineer of the construction to make changes on the initial planning.

It is also identified as a critical factor the supplier's support. That is evidenced by the fact that the two companies reported the difficulty at servicing the supplier and that their internal crews had much more knowledge of the product than the supplier's crew (A7, B1).

The version updates are the most critical points, because they, as a general rule, present problems (A7, B1). As mitigation of the problem, company A chose to keep themselves always one version before the current, waiting the supplier's maturing based on the experience with other clients. The organization also benefits from the fact that they implemented the standard version, since the problems are limited to the model product, and the responsibility of solving any problem is entirely on the supplier (A5).

The product usage allowed significant improvements for company $A$, as a result of the crew's development, through the discovery of new features in the system, though the identification/correction of errors of rules in the system and the company, as well as the product evolution.

Company $\mathrm{B}$ also has been demonstrating a posture of constant analysis of the ERP's potential and, every time they identify improvements or reasonable adherence to their processes, they have been incorporating new ERP modules instead of developing them, as a property control solution (B5).

The organizations have been trying to participate in user forums created by the supplier, which allows not only to get to know the system's changes and evolutions, but also the exchange of experience with other clients. That has been bringing more maturity to their crews and it is in accordance to the academia, which suggests as an important thing wide user integration (Bajwa \& Garcia, 2004).

As a critical factor of success at the operation step, it was identified that the effective gain of ERP's benefits is related to a policy of analysis of the system changes and to the user training, which allows to identify features that help at the improvement of data and controls.

\section{Conclusion}

The analyses carried out this research identified that the ERP usage in the production function of civil construction companies is feasible. However, its implementation, in order to bring effective benefits, is much more related to organizational policies than to its features.

The features that were, in the past, decisive to the fact that ERP was not used in production are not a big problem nowadays, given its evolution over the past 10 years, as it was identified in the interviewee's discourses.

However, even with features not being the biggest hindrance, it is fundamental that the ERP contain minimality the characteristics pointed out on Table 1.

As a result of this research, there were factors identified as main critical facts of success the ones related on Table 4. 
Table 4. Critical factors of success for the ERP implementation.

\begin{tabular}{|c|c|}
\hline Critical factor of success & Description \\
\hline Planning culture & $\begin{array}{l}\text { The controls provided by ERP are based on the definition of the } \\
\text { activities, their resources and sequencing, thus its usage will be } \\
\text { effective only if the planning is effective. }\end{array}$ \\
\hline Strategic guideline & $\begin{array}{l}\text { The company's strategic guideline may be an inhibitor to ERP } \\
\text { usage in production, if planning is not an organizational value. }\end{array}$ \\
\hline $\begin{array}{l}\text { Production management } \\
\text { model }\end{array}$ & $\begin{array}{l}\text { Way in which the company plans, executes, and controls their } \\
\text { enterprise. }\end{array}$ \\
\hline $\begin{array}{l}\text { Commitment from the } \\
\text { senior management }\end{array}$ & $\begin{array}{l}\text { Important in ensuring resources, mediating conflicts and, } \\
\text { especially, to ensure that the strategic options do not suffer from } \\
\text { discontinuity. }\end{array}$ \\
\hline $\begin{array}{l}\text { Ability to support and } \\
\text { experience from the } \\
\text { supplier's crew }\end{array}$ & $\begin{array}{l}\text { The knowledge of the product and the experience in the } \\
\text { implementation are fundamental, especially considering that they } \\
\text { will be productive processes being implemented. It is also } \\
\text { fundamental to ensure that the problems are solved in an efficient, } \\
\text { quick way. The supplier's experience also includes the knowledge } \\
\text { in the processes of construction planning. }\end{array}$ \\
\hline Supplier's assessment & $\begin{array}{l}\text { It concerns the financial health, posture regarding improvements in } \\
\text { the products, credibility to other clients. }\end{array}$ \\
\hline $\begin{array}{l}\text { Usage of independent } \\
\text { consulting }\end{array}$ & $\begin{array}{l}\text { Considering the sector's little familiarity with innovation and } \\
\text { organizational changes, little experience with technology and the } \\
\text { fact that implementation happens only one time, having a } \\
\text { consulting that helps the process is important. }\end{array}$ \\
\hline Implementation strategy & $\begin{array}{c}\text { Having in mind the volume of changes and impact on the company } \\
\text { (processes, control, people), the construction individuality, the } \\
\text { resistances, the professionals limitations, the definition of strategy } \\
\text { is CFS. It is understood that the small-bang (pilot construction) } \\
\text { necessarily must be adopted. }\end{array}$ \\
\hline ASP & $\begin{array}{l}\text { The way how the ASP is defined will determine the quality and } \\
\text { feasibility of the management of the enterprise. }\end{array}$ \\
\hline Training & $\begin{array}{c}\text { Without it the usage of the ERP is impossible. Its quality is also } \\
\text { important, because without it there could be under-utilization of the } \\
\text { system. Moreover, its lack is a factor of resistance to the } \\
\text { implementation. }\end{array}$ \\
\hline $\begin{array}{l}\text { Registration of materials } \\
\text { and compositions }\end{array}$ & $\begin{array}{c}\text { Fundamental data to the cost building and the identification of the } \\
\text { resources that are needed to the execution of the activities. It has } \\
\text { an impact on the sizing of the crew, the service hiring, and the } \\
\text { purchases. }\end{array}$ \\
\hline Engineer profile & $\begin{array}{c}\text { The ERP emphasize the manager's management profile, besides } \\
\text { the fact that the production management model provided by the } \\
\text { ERP demand a planning profile. }\end{array}$ \\
\hline Stockman profile & $\begin{array}{c}\text { The ERP implementation demands that the stockman has } \\
\text { knowledge of operating a computer, tax notions, kwnoledge of } \\
\text { services; usually, that professional has a very low educational } \\
\text { level. }\end{array}$ \\
\hline System technology & $\begin{array}{c}\text { The ERP technology may be impeditive to usage of this system in } \\
\text { sites with low quality communication structure or also demand a } \\
\text { very high cost of maintenance. }\end{array}$ \\
\hline
\end{tabular}

Source: Elaborated by the authors.

The previously mentioned organizational policies concern the critical factors of success: planning culture, strategic guidelines that subordinate the decision only to the cost, profile of the professionals with emphasis on the engineer, and production management model. 
The relevance of the planning culture reside on the fact that it is through planning that are identified the human and material resources necessary to the building of the enterprise. It is also through it that is identified the best activity flux to the execution of the enterprise and it is also possible to control if those are being performed within the specified costs and deadline.

The strategic guideline was already discussed before, but it is relevant to restate that, if the company does not have the perception of how they see their management, they might venture in a process that is expensive, long and impactful on the organization, since it will make choices of processes that are incoherent to their controls.

The strategic guideline, as it was seen, was decisive to company B's choice of not implementing ERP in the production. It is not up to this research no analyze if there was an understanding problem, but it is to realize that the companies have an organizational culture and that the latter cannot be absolutely disregarded, under the risk of failure or tardiness in the implementation process. It is a critical factor of success and it is aligned to what academia says.

Concerning the operation management model, it has an impact on the data organization, the building of the ASP, and staff's profile. As it was identified, company $B$ assign to the engineer a lot of independence on the planning, creating a lack of standardization, which is contradictory to the ERP, which provides with the standardization of processes the solution to a better management, control and rationalization.

Although these are the most relevant CFS and they have been the differential in this research, there are some considerations on other groups that are worth making.

One of them is linked to the supplier, in what is related to its capacity of support, its crew experience, and its assessment. To select a supplier that can ensure the product's continuity and evolution, the functional and technical support is fundamental. Both companies had problems with the supplier. That could be minimized with the elaboration of a well-defined assessment script, data check, assembly of a multidisciplinary crew (technical and businesswise) to assess the ERP, and keeping contact to other clients, according to what was suggested by Tonini (2003).

Other group would be those linked to the staff qualification: training, engineer profile, stockman profile.

Staff qualification is related to the change brought by the ERP, which was significant to the companies. Thus, ensuring the professionals training, as much in the implementation period as in the maintenance period during the operation, is fundamental to bring maturity to the crew and to the company's management. It is worth highlighting the importance of the engineer's training, direct responsible of the enterprise, with a lot of decision and veto, as well as the stockman's, since he is the one who has the responsibility on data entry (invoice, stock movement, material usage pointing).

Another cluster of critical factors of success would be the data structure: ASP and the registration of materials and composition. Those elements are fundamental, because they influence directly on the planning structure and the composition of costs and allocation of resources, impacting not only on the enterprise deliveries, but also on the planning of the cash flow.

Finalizing the considerations on the critical factors of success, it is worth to highlight the board of directors' participation as a conflict-solving instance, playing and active role throughout the process. The decision made by company $\mathrm{B}$ presents until this day 
relevant cost consequences, difficulties with product evolution, high learning curve. They are decision that cannot be taken by the company's middle-level, even if their opinion is relevant.

It is understood that this research achieved its objective by identifying the critical facts of success for the ERP implementation in the production function, although part of such factors also influences on other processes. This research also brought as a new contribution to research on ERP the adding of three critical factors of success: planning culture, strategic guideline, and production management model. None of those factors were mentioned in the researched literature. Moreover, it gave a new relevance to the function of the supplier's role, previously identified in Mendes \& Escrivão (2002) as a critical factor, but with minor relevance.

This paper benefits, especially, the construction industry by providing subsidies that will be able to minimize the implementations risks or also contribute to the decision on the feasibility or not of adopting ERP.

It is suggested as future research the application of this research in other companies, in order expand/validate the variables considered here, in companies with other ERPs, for example.

It is also suggested to check the influence of the cost on the company's strategic guideline, given its great impact on the implementation process, as well as checking on solutions that minimize such impact.

\section{References}

Ahmed, S. M., Ahmad, I., Azhar, S., \& Mallikarjuna, S. (2003). Implementation of Enterprise Resource Planning (ERP) systems in the construction industry. In Construction Research Congress 2003. Reston: American Society of Civil Engineers. http://dx.doi.org/10.1061/40671(2003)125.

Akkermans, H., \& Van Helden, K. (2002). Vicious and virtuous cycles in ERP implementations: a case study of interrelations between critical success factors. European Journal of Information Systems, 11(1), 35-46. http://dx.doi.org/10.1057/palgrave.ejis.3000418.

Bajwa, D. S., \& Garcia, J. E. (2004). An integrative framework for the assimilation of enterprise resource planning systems: phases, antecedents, and outcomes. Journal of Computer Information Systems, 44(3), 81-90.

Câmara Brasileira da Indústria da Construção - CBIC. (2017). Retrieved in 2017, September 13, from http://www.cbic.org.br

Chung, B. Y., Skibniewski, M. J., Lucas, H. C., Jr., \& Kwak, Y. H. (2008). Analyzing enterprise resource planning system implementation success factors in the engineering-construction industry. Journal of Computing in Civil Engineering, 22(6), 373-382. http://dx.doi.org/10.1061/(ASCE)0887-3801(2008)22:6(373).

Creswell, J. W. (2010). Projeto de pesquisa: métodos qualitativo e quantitativo (3. ed.). Porto Alegre: Artmed.

Etchalus, J. M., Xavier, A. A. P., \& Scandelari, L. (2006). Aspectos da tecnologia da informação em pequenas empresas da construção civil. Synergismus Scyentifica UTFPR, 1(1-4), 1778.

Federação das Indústrias do Estado de São Paulo - FIESP. Departamento da Indústria da Construção. (2008). Proposta de política industrial para a construção civil: edificações (Caderno, 1). São Paulo. Retrieved in 2017, September 13, from http://www.forumdaconstrucao.com.br/conteudo.php?a=0\&Cod=348

Flick, U. (2009). Introdução a pesquisa qualitativa (3a ed., J. E. Costa, Trad.). Porto Alegre: Artmed. 
Krainer, C. W. M., Krainer, J. A., larozinski, A., No., \& Romano, C. A. (2013). Análise do impacto da implantação do sistema ERP nas características organizacionais das empresas de construção civil. Ambiente Construído, 13(3), 117-135. http://dx.doi.org/10.1590/S167886212013000300008.

Kroenke, D. M. (2012). Sistemas de Informação gerenciais (L. E. T. Frazão Filho, Trad.). São Paulo: Saraiva.

Laukkanen, S., Sarpola, S., \& Hallikainen, P. (2005). ERP system adoption: does the size matter? In Proceedings of the 38th Annual Hawaii International Conference on System Sciences. Los Alamitos: IEEE Computer Society Press. http://dx.doi.org/10.1109/HICSS.2005.245.

Luo, W., \& Strong, D. M. (2004). A framework for evaluating ERP implementation choices. IEEE Transactions on Engineering Management, 51(3), 322-333. http://dx.doi.org/10.1109/TEM.2004.830862.

Mendes, J. V., \& Escrivão, E., Fo. (2002). Sistemas integrados de gestão ERP em pequenas empresas: um confronto entre o referencial teórico e a prática empresarial. Gestão \& Produção, 9(3), 277-296. http://dx.doi.org/10.1590/S0104-530X2002000300006.

Monteiro, D. C., Costa, A. C. R., Fa., \& Rocha, É. R. P. (2010). Perspectivas e desafios para inovar na construção civil. BNDES Setorial, 31, 353-410.

Morgan, G. (2007). Paradigmas, metáforas e resolução de quebra-cabeças na teoria das organizações. In M. Caldas \& C. O. Bertero (Eds.), Teoria das organizações. São Paulo: FGV/RAE/Atlas.

Nascimento, F. P. (2007). Uma proposta metodológica para uma implantação de um ERP orientada a gestão de mudanças (Dissertação de mestrado). Universidade Estadual de Santa Catarina, Florianópolis.

O'Connor, J. T., \& Dodd, S. C. (2000). Achieving integration on capital projects with enterprise resource planning systems. Automation and Robotics in Construction, 9(5-6), 515-524. http://dx.doi.org/10.1016/S0926-5805(00)00062-5.

Padilha, T. C. C., \& Marins, F. A. S. (2005). Sistemas ERP: características, custos e tendências. Revista Produção, 15(1), 102-113. http://dx.doi.org/10.1590/S010365132005000100009 .

Pasqualini, F. (2005). Fluxo de valor na construção de edificações habitacionais: estudo de caso em construtora de Porto Alegre/RS (Dissertação de mestrado). Universidade Federal do Rio Grande do Sul, Porto Alegre.

Ram, J., Corkindale, D., \& Wu, M. (2013). Implementation critical success factors (CSFs) for ERP: do they contribuite to implementation success and postimplementation performance? International Journal of Production Economics, 144(1), 157-174. http://dx.doi.org/10.1016/j.ijpe.2013.01.032.

Roesch, S. A. (2006). Projetos de estágio e de pesquisa em administração: guia para estágios, trabalhos de conclusão, dissertações e estudos de caso (3. ed.). São Paulo: Atlas.

Scheer, S., Amorim, S. R. L., Santos, E. T., Ferreira, R. C., \& Caron, A. M. (2007). The scenario and trends in Brazilian IT construction applications experience. ITCon, 12, 193-206.

Shi, J. J., \& Halp In, D. W. (2003). Enterprise resource planning for construction business management. Journal of Construction Engineering and Management, 129(2), 214-221. http://dx.doi.org/10.1061/(ASCE)0733-9364(2003)129:2(214).

Skibniewski, M. J., \& Ghosh, S. (2009). Determination of key performance indicators with enterprise resource planning systems in engineering construction firm. Journal of Construction Engineering and Management, 135(10), 965-978. http://dx.doi.org/10.1061/(ASCE)0733-9364(2009)135:10(965). 
Sousa, A. M. H. (2014). Um estudo sobre o processo de implantação de sistemas ERP na função produção de empresas da construção civil (Dissertação de mestrado). Universidade Federal Ceará, Fortaleza.

Souza, C. A. (2000). Sistemas integrados de gestão empresarial: estudos de casos de implantação de sistemas ERP (Dissertação de mestrado). Universidade de São Paulo, São Paulo.

Souza, C. A., \& Zwicker, R. (2003). Big-bang, small-bang ou fases: estudo dos aspectos relacionados ao modo de início de operação de sistemas ERP. Revista Administração Contemporânea, 7(4), 9-31. http://dx.doi.org/10.1590/\$1415-65552003000400002.

Tatari, O., Castro-Lacouture, D., \& Skibniewski, M. J. (2007). Current state of construction enterprise information systems: survey research. Construction Innovation, 7(4), 310-319. http://dx.doi.org/10.1108/14714170710780075.

Tatari, O., Castro-Lacouture, D., \& Skibniewski, M. J. (2008). Performance evaluation of construction enterprise resource planning systems. Journal of Management Engineering, 24(4), 198-206. http://dx.doi.org/10.1061/(ASCE)0742-597X(2008)24:4(198).

Tonini, A. C. (2003). Metodologia para seleção de sistemas ERP: um estudo de caso. In C. A. Souza \& A. Z. Saccol (Eds.), Sistemas ERP no Brasil: teoria e casos (pp. 29-60). São Paulo: Atlas.

Vieira, H. F. (2006). Logística aplicada à construção civil: como melhorar o fluxo de produção nas obras. São Paulo: PINI.

Yang, J., Wu, C., \& Tsai, C. (2007). Selection of na ERP system for a construction firm in Taiwan: a case study. Automation in Construction, 16(6), 787-796. http://dx.doi.org/10.1016/j.autcon.2007.02.001.

Zeng, Y., Lu, Y., \& Skibniewski, M. J. (2012). Enterprise resource planning systems for projectbased firms: benefits, costs \& implementation challenges. Journal for the Advancement of Performance Information and Value, 4(1), 85-96. 